\section{Tuberous sclerosis complex and its founders}

A though the names of Bourneville and Pringle are associated with the disease they were not the first who reported patients with signs later defined as the diagnostic criteria. Reports start in the 19th century and are based on descriptions of clinical and pathological findings.

The characteristic skin lesions were mentioned for the first time in 1835. Rayer's atlas on skin diseases illustrates the facial "végétations vasculaires". These lesions were renamed adenoma sebaceum by Pringle, who is remembered today for his description of a patient with adenoma sebaceum. ${ }^{1}$ He also mentioned the associated mental subnormality.

In 1862 Von Recklinghausen, primarily associated with neurofibromatosis, first mentioned the cerebral involvement. On autopsy of a newborn that died a few minutes after birth, he found cardiac myomata and sclerotic brain lesions, but he did not make the association between the two pathologies. Description of the cerebral pathology and neurological signs is credited, however, to Bourneville. He proposed the term sclérose tubéreuse des circonvolutions cérébrales to characterise the large islets of sclerosis he found in the cortical gyri of two patients who died of epilepsy. ${ }^{23}$ He found kidney masses in one of the patients as well.

It was in the beginning of the 20th century that a more complete clinical picture of tuberous sclerosis complex (TSC) was obtained. The association between the cerebral, renal, cardiac, and dermal lesions was first recognised in 1905, leading to the clinical diagnostic triad consisting of epilepsy, idiocy, and adenoma sebaceum, often called after Vogt. Van der Hoeve, who characterised the retinal hamartomas, introduced the name phakomatosis (phakos means spot), comprising both TSC and neurofibromatosis. After the first descriptions of radiological calcifications, the introduction of the CT and MRI scans greatly improved the diagnostic process. Gomez, the "godfather of TSC research", first published the full clinical and subclinical spectrum of TSC in $1979 .{ }^{4}$

The hereditary basis of TSC was mentioned as early as 1913. Positional cloning studies led to the identification of TSCl with the locus on chromosome 9, and TSC2 with the locus on chromosome 16. Better insight in the putative molecular mechanisms underlying the development of the hamartomatous lesions has yet to be achieved.

\section{The founders of the disease Désiré Magloire Bourneville (1840-1909)}

Bourneville $e^{5}$ was born on 21 October 1840 in Garencières, Normandy, France. Although a cholera epidemic prevented him from completing secondary school, he entered the Paris Medical Faculty in 1860, on recommendation of Delasiauve, first a family friend, later one of his mentors. In 1865 he became resident of the Paris hospitals. From 1868 Bourneville became the "unofficial" assistant of Charcot at the Salpêtrière hospital, where he was appointed as head of the department of psychiatry. A remarkable relation between the two men arose.

Bourneville's scientific career started in 1861. His doctoral thesis was submitted in 1870 . He was the founder of many journals; namely La Mouvement Medical (1865), La Clinique de L Hôpital Saint-Louis (1868), Le Progrès Médical (1873), and Archives de Neurologie (1880). Bourneville's own viewpoints were promoted in Le Progrès Médical, which became considerably popular and influential. In the period of the third republic, Bourneville, as a medical reformist, was attracted to the political platform. He was elected municipal councilor in 1876. During this period his efforts included upgrading the deteriorated state of the old Paris hospitals and improving training for nurses and midwives. Later he became a member of the parliament for the extreme left wing party (18831889). Being both a physician and a republican was his ideal. His fame started to fall in the early 1890s and became irreversible after Charcot's death in 1893. In 1905 Bourneville took compulsory retirement. He died as a poor man in 1909.

\section{John James Pringle (1855-1922)}

John James Pringle ${ }^{6}$ was born in 1855 in Dumfriesshire, Scotland. In 1876 he qualified in medicine at the Edinburgh University. After a residency at the old Edinburgh Royal Infirmary, he spent four years in Vienna and Paris. His dandy like appearance, excellent knowledge of French, and his punctuality resulted in admiration among the foreign dermatologists. From 1883 he worked at the skin department at the Middlesex Hospital in London, and took charge in 1888. From 1891 to 1895 he edited the British Journal of Dermatology. Due to the long lasting friendships with foreign dermatologists, the journal had an international character from the start. Because of his many ambassadorial skills he was appointed Secretary General to the International Congress of Dermatology in 1896. From 1895 to 1901 he was Secretary of the Dermatological Society. He became a successful president of the dermatology section of the Royal Society of Medicine. Even during the difficult war times, 1914-1918, Pringle was able to initiate lively discussions during the meetings. He further made a special effort in training his assistants and teaching medical students. He contributed to the Royal Commission of Venereology (1916). A remarkable man who's neat appearance, humour, and affection to dermatology made him a legend of his time. In 1922 he died in New Zealand from tuberculosis, which he had suffered for 17 years.

F E Jansen
O van Nieuwenhuizen
Department of Child Neurology, University Medical Center, Utrecht,
The Netherlands
A C van Huffelen
ment of Clinical Neurophysiology, University Medical Center, Utrecht,
The Netherlands

Correspondence to: F E Jansen, Department of Neurology, C03230, UMC, PO Box 85500, 3508 GA Utrecht, The Netherlands; f.e.jansen@neuro.azu.n

\section{References}

1 Pringle JJ. A case of congenital adenoma sebaceum. Br J Dermatol 1890;2:1-14

2 Bourneville DM. Sclérose tubéreuse des circonvolutions cérébrales. Arch Neurol 1880;1:81-91.

3 Bourneville DM, Brissaud E. Encéphalite ou sclérose tubéreuse des circonvolutions cérébrales. Arch Neurol (Paris) 1881;1:390-410.

4 Gomez MR. Tuberous Sclerosis Complex. New York: Oxford University Press, 1999.

5 Poirier J, Chretien F. Desire Bourneville (1840-1909). J Neurol 2000;247:481.

6 Lyell A. The man behind the eponym. John James Pringle (1855-1922). Am J Dermatopathol 1985;7:441-5. 